\title{
Controle externo do Legislativo sobre as contas da Administração Pública Municipal
}

Poliane Denobi ${ }^{1}$

\section{Resumo}

O presente estudo, baseado no método indutivo, realizado por meio de pesquisa bibliográfica e estudo de caso, examina o procedimento e a eficácia do controle externo que o Legislativo exerce sobre as contas prestadas anualmente pelo Executivo no âmbito da Administração Pública Municipal. Aponta as críticas doutrinárias à eficiência do controle. Como resultado da pesquisa constatou-se que a legislação pertinente ao assunto e a prática desse controle têm se mostrado ineficaz, estimulando a corrupção e a impunidade.

Palavras-Chave: Controle externo; Prestação de contas; Tribunal de Contas; Câmara Municipal de Vereadores.

\section{Introdução}

O Legislativo caracteriza-se por elaborar leis, ou seja, introduzir no ordenamento normas abstratas e gerais que inovam a ordem jurídica. Seu papel não se resume a essa função típica. Uma das funções atípicas de competência do Legislativo é a de exercer o controle externo sobre as contas da Administração Pública.

A Constituição Federal conferiu ao Legislativo a competência para julgar e fiscalizar as contas do Executivo, compreendendo a administração direta e indireta ${ }^{2}$. No âmbito municipal, compete à Câmara de Vereadores a função de exercer o controle sobre as contas que devem ser prestadas, anualmente, pelo Chefe do Executivo, conforme o artigo 31 da Constituição Federal.

A função de controlar e fiscalizar as contas se desenvolve por meio de um processo. É por este processo, já contando com o parecer prévio do Tribunal de Contas do Estado que as contas serão submetidas a julgamento pela Câmara de Vereadores, que deve seguir o

Especialista em Direito do Estado - Direito Administrativo pela Universidade Estadual de Londrina.

2 Art. 49. É da competência exclusiva do Congresso Nacional:

IX - julgar anualmente as contas prestadas pelo Presidente da República e apreciar os relatórios sobre a execução dos planos de governo;

$\mathrm{X}$ - fiscalizar e controlar, diretamente, ou por qualquer de suas Casas, os atos do Poder Executivo, incluídos os da administração indireta. 
procedimento consagrado no Regimento Interno da Casa Legislativa e na Lei Orgânica do Município. ${ }^{3}$

Para o exercício do controle das contas municipais pelo Legislativo, além da Constituição Federal e da respectiva Constituição Estadual, também devem ser observados: a Lei Orgânica do Município; o Regimento Interno da Casa Legislativa; a legislação referente ao Tribunal de Contas do Estado; a Lei Nacional no 4.320, de 17 de março de 1964, que estatui normas gerais de Direito Financeiro para elaboração e controle dos orçamentos e balanços da União, Estados Federados, Distrito Federal e Municípios; e a Lei Complementar 101, de 04 de maio de 2000, que estabelece normas de finanças públicas voltadas para a responsabilidade na gestão fiscal.

Com base nesta legislação passa-se a discorrer sobre o procedimento do controle externo, abordando a participação do Tribunal de Contas do Estado no exercício da sua função opinativa e a atuação das Câmaras Municipais, apontando algumas das inconstitucionalidades constantes nos regimentos internos dos Municípios estudados para que, diante do exposto, se possibilite posicionar-se sobre a sua ineficiência.

\section{Prestação das contas pelo chefe do executivo}

De acordo com o art. 70, parágrafo único da Constituição Federal, estão sujeitos ao controle e devem prestar contas qualquer pessoa física ou jurídica, pública ou privada, que utilize, arrecade, guarde, gerencie ou administre dinheiro, bens e valores públicos ou pelos quais a União responda, ou que, em nome desta, assuma obrigações de natureza pecuniária.

Esse comando constitucional se aplica à União, aos Estados e aos Municípios, indicando os sujeitos que serão passíveis ao controle dos gastos públicos, ou seja, todo aquele responsável pelo Erário tem a obrigação constitucional e o dever moral de zelar pelo que pertence à coletividade.

Sobre o que se refere as contas que o Chefe do Executivo deve, anualmente, prestar José Rubens Costa (apud AMARAL, 2000, p. 24) ensina que:

A Constituição, ao se referir ao Presidente ou às contas a serem anualmente prestadas por ele, o situa como representante da pessoa jurídica de direito público

3 Para a realização do presente estudo foram utilizados como parâmetro a Lei Orgânica e o Regimento Interno dos Municípios de Jandaia do Sul, Santa Mariana e Londrina, todos no Estado do Paraná. 
interno, membro da Federação, União, (grifo do original) assim como os Governadores e Prefeitos o são dos Estados e Municípios. A prestação de contas não é responsabilidade do Poder Executivo, mas do Governo, com o que se apresenta de modo unitário e global com relação a todos os Poderes e órgãos administrativos. Isso porque a prestação de contas é o reverso do sistema orçamentário. Prestam-se contas para que se verifique, antes de tudo, se houve cumprimento do Plano Plurianual, Lei de Diretrizes Orçamentárias e Lei Orçamentária Anual (art. 165).

Quanto ao prazo que as contas devem ser prestadas, de acordo com a Lei $n=4.320$, de 17 de março de 1964, deve ocorrer conforme o prazo definido na Lei Orgânico do Município:

Art. 82. O Poder Executivo, anualmente, prestará contas ao Poder Legislativo, no prazo estabelecido nas Constituições ou nas Leis Orgânicas dos Municípios.

$\S 1$ 을 As contas do Poder Executivo serão submetidas ao Poder Legislativo, com parecer prévio do Tribunal de Contas ou órgão equivalente.

Segundo as leis orgânicas e os regimentos internos dos Municípios analisados e o provimento no 3/91 do Tribunal de Contas do Estado do Paraná, o Prefeito Municipal deve encaminhar, até 31 de março de cada ano ao Tribunal de Contas do Estado a prestação das contas municipais.

Não sendo as contas prestadas dentro de sessenta dias após a abertura da sessão legislativa, a Câmara Municipal proceder-lhes-á a tomada, em consonância com o que dita o seu regimento interno e a Constituição Federal no art. 51, II para o modelo federal.

Uma vez não prestadas as contas anuais do Município ou que as tendo prestado com graves irregularidades, até que sejam sanadas, ao Tribunal de Contas compete representar à repartição pública federal ou estadual pelo bloqueio das transferências de recursos destinados ao Município, além da possibilidade de acarretar a intervenção do Estado no respectivo Município (art. 35, II, CF).

Em sendo prestadas as contas pelo Chefe do Executivo, serão remetidas ao Tribunal de Contas do Estado que deverá apreciá-las e emitir parecer prévio sobre a sua regularidade a fim de instruir a decisão definitiva do Legislativo. 


\section{0 tribunal de contas no exercício da função opinativa}

O controle externo tem caráter político, cujo titular é o Legislativo, mas que, devido ao caráter técnico e a complexidade com que se reveste um processo de prestação de contas e para melhor desempenhar a função de controle externo, as Casas Legislativas contam com o auxílio de um órgão especializado que é o Tribunal de Contas. Segundo Costa, N. (2000, p. 133):

a Câmara Municipal é o Poder que faz realmente o controle das contas do Executivo local, através de processo de julgamento político, de modo que no Tribunal de Contas ocorre apenas um processo administrativo de controle (destacou-se).

O Tribunal de Contas exerce a função de auxiliar o Legislativo no exercício do controle externo sobre a atividade financeira e orçamentária da Administração Pública. Para tanto emite parecer prévio sobre as contas prestadas, anualmente, pelo Chefe do Executivo, segundo determina 0 art. $71, \mathrm{l}$, da Constituição Federal ${ }^{4}$, não podendo o Legislativo prescindir dele, no exercício da função fiscalizadora.

Prestada as contas pelo Chefe do Executivo e sendo remetidas ao Tribunal de Contas, a este competirá apreciá-las em sessenta dias e emitir parecer prévio sobre a sua regularidade, baseado em relatório de auditoria, a fim de instruir a decisão definitiva do Legislativo.

Além do parecer prévio, o Tribunal de Contas contribui com o controle externo por meio de prestação de informações solicitadas pelo Legislativo e por meio da realização de auditorias e inspeções com caráter instrutório (art. 71, VII, CF). Sobre a importância da realização de inspeções e auditorias defende Souza $(1996$, p. 171) que:

A operacionalidade e a eficácia do controle externo da Administração Pública estão, desse modo, asseguradas pela possibilidade constitucional de o Poder Legislativo reclamar ao Tribunal de Contas a realização de inspeções e auditorias especiais, revestidas de adequado cuidado técnico, indispensável e impositivo diante da complexidade de que se reveste a moderna administração pública, quando tratamos do controle denominado parlamentar puro, isto é, de caráter político, com auxílio do órgão técnico especial constituído para este fim.

\footnotetext{
4 No mesmo sentido o art. 75 e 18 da Constituição do Estado do Paraná, e em nível municipal a Constituição
} Federal dispõe no art. 31, §1ㅇ. 
Por meio do parecer prévio, pode aprovar as contas integralmente ou aprovar com ressalvas, quando elencará as providências necessárias para sanar as irregularidades apontadas. Poderá opinar pela sua reprovação, uma vez comprovada: a omissão no dever de prestá-las; a prática de ato de gestão ilegal, ilegítimo, antieconômico, ou grave infração à norma legal ou regulamentar de natureza contábil, financeira, orçamentária, operacional ou patrimonial; dano ao Erário decorrente de ato de gestão ilegítimo ou antieconômico; desfalque ou desvio de dinheiros, bens ou valores públicos.

O Supremo Tribunal Federal manifestou-se no sentido de que a aprovação política das contas do Chefe do Executivo não libera do julgamento os responsáveis pela gestão financeira das demais unidades orçamentárias, inclusive as pertencentes ao Executivo. ${ }^{5}$

O Superior Tribunal de Justiça reconheceu a possibilidade do Tribunal de Contas reexaminar as contas do Executivo mesmo que o Legislativo as tenha aprovado, a fim de verificar irregularidades. Como bem acentua Santos (2003, p. 75):

\begin{abstract}
A atribuição de elaborar parecer prévio sobre as contas apresentadas pelo Presidente da República (função consultiva) em nada se confunde com o fato de cada unidade da administração direta e indireta prestar contas da sua gestão ao Tribunal de Contas, que procederá ao seu julgamento independentemente do pronunciamento do Poder Legislativo. Neste último caso, o TCU exerce função judicante. Com efeito, por imperativo constitucional, cabe ao Tribunal julgar as contas dos administradores e dos demais responsáveis por dinheiros, bens e valores públicos da administração direta e indireta, incluídas as fundações e sociedades instituídas e mantidas pelo Poder Público Federal, bem como as contas daqueles que derem causa a perda, extravio ou outra irregularidade de que resulte prejuízo ao Erário público (CF, art. 71, inc. II) (grifo do autor).
\end{abstract}

Depois de elaborado o parecer prévio contendo a manifestação do Tribunal de Contas no sentido da regularidade ou irregularidade das contas, será remetido cópia do mesmo à Câmara Municipal que deverá realizar o julgamento de acordo com o prazo contido no seu regimento interno.

5 ADIn 849/MT, sessão do dia 11.02.1999, publicada no DJU de 23.04.1999. 


\section{Análise do parecer prévio pela Comissão de Finanças e Orçamento da Câmara Municipal}

O art. 166, $\S 1$ 1ํ, I da Constituição Federal determina que caberá a uma Comissão mista permanente de Senadores e Deputados examinar e emitir parecer prévio sobre as contas prestadas anualmente pelo Presidente da República. Considerando o disposto no art. 75 , simetricamente o mesmo deve ser observado no julgamento das contas municipais.

Desta maneira, após o pronunciamento do Tribunal de Contas, compete à Comissão de Finanças e Orçamento da Câmara de Vereadores conhecer e apresentar parecer sobre a prestação de contas do Executivo.

A Comissão de Finanças e Orçamento é órgão interno da Câmara Municipal destinado a praticar atos simplesmente administrativos. Conforme Meirelles (2001, p. 617) "as comissões não legislam, não deliberam, não administram nem julgam; apenas analisam, investigam e apresentam conclusões ou sugestões, concretizadas em pareceres de caráter meramente informativo para o plenário":

\footnotetext{
Comissões são órgãos técnicos, integrados por Vereadores, para que melhor possam analisar determinados projetos de lei, além de ter condições de empreender algumas investigações. Cabe ao Plenário escolher os membros das Comissões, dentre os pares com condições de enfrentar os problemas técnicos que passará a estudar. Os pareceres não obrigam ao Plenário, mas do ponto de vista técnico devem ser observados (COSTA, 2000, p. 159).
}

Recebido o parecer prévio do Tribunal de Contas, o Presidente da Câmara distribuirá cópia do mesmo e do balanço anual aos vereadores e enviará o processo à Comissão de Finanças e Orçamento. A Comissão deve opinar sobre as contas e apresentar ao Plenário o projeto de Decreto Legislativo consubstanciado no seu parecer, recomendando ou não a aprovação das contas.

Neste período a prestação de contas da Administração direta e indireta e o parecer prévio do Tribunal de Contas ficam a disposição por sessenta dias para que qualquer do povo analise a sua legitimidade.

Os vereadores têm a faculdade de solicitar à Comissão de Finanças e Orçamento pedidos escritos sobre informações de itens determinados da prestação de contas. Cabe aos 
vereadores acompanhar os estudos da Comissão no período em que o processo estiver com a mesma.

Para uma maior elucidação dos fatos pode a Comissão de Finanças e Orçamento vistoriar obras e serviços, examinar processos, documentos e papéis nas repartições da Prefeitura, bem como solicitar esclarecimentos complementares ao Prefeito.

A Comissão também tem a faculdade de contratar peritos com a finalidade de ajuda-los na análise da prestação de contas, segundo estabelece o Regimento Interno e a Lei no 4.320 de 17 de março de 1964 no seu art. 84: "Art. 84. Ressalvada a competência do Tribunal de Contas ou órgão equivalente, a Câmara de Vereadores poderá designar peritos contadores para verificarem as contas do prefeito e sobre elas emitirem parecer".

O parecer da Comissão deve ser assinado pelos seus membros, devendo o voto contrário ser apresentado em separado com as suas razões. O projeto de Decreto Legislativo apresentado pela Comissão será submetido a discussão e votação em sessões exclusivamente dedicadas ao assunto.

\section{Capacidade técnica dos membros da Comissão de Finanças e Orçamento da}

\section{Câmara Municipal}

Os membros da Comissão de Finanças e Orçamento da Câmara Municipal no exercício desta função, em teoria, analisam as contas sob a ótica técnica e, depois, na função de vereadores quando da votação em Plenário, julgam de maneira política o mesmo processo de prestação de contas. Desta maneira, o parecer da Comissão se restringe ao assunto de sua especialidade, a ser emitido do ponto de vista técnico, e não político. Assim preceitua Meirelles (2001, p. 619):

\footnotetext{
Desde que as comissões são órgãos formados com intuitos técnicos, sobressai a conveniência de se distribuírem os vereadores segundo sua especialidade e formação profissional, para que se obtenha o máximo rendimento e a maior autoridade nos pareceres que forem exarados. Comissões técnicas sem membros técnicos, sobre ser uma inutilidade, é um contra-senso que merece ser evitado pelas Câmaras.
}

Diante da finalidade da função que exercem, é possível concluir que os membros pertencentes à Comissão de Finanças e Orçamento deveriam possuir especialidade e 
formação profissional para integrarem esta Comissão técnica, para que se obtivesse pareceres especializados, tendo uma maior legitimidade na sua atuação, podendo os membros opinar com autoridade, fundamentando seu posicionamento.

Questiona-se como é possível à Comissão recomendar a desaprovação de uma prestação de contas do Executivo se muitas vezes seus membros não possuem especialidade e formação técnica suficientes para entender a complexidade que envolve as finanças de um Município e, mesmo assim, não solicitam a ajuda de profissionais da área. Neste aspecto, defende Amaral (2000, p. 60-61):

Nestas circunstâncias, urge que as Câmaras Municipais busquem assessoria eficiente nas áreas jurídicas e técnica específica, para dar-lhes suporte de validade aos seus julgamentos e obterem nível de credibilidade, mesmo porque se sabe que os vereadores são oriundos de diversas áreas e profissões, mas muitos deles, principalmente nos pequenos municípios, não possuem o esclarecimento necessário ou tão abrangente para abordar tais situações.

Guerra (2003, p. 67) explicita o que corresponde a uma realidade vivida pelo País:

Na prática, o que se percebe é que muitas Câmaras Municipais realizam um julgamento do parecer prévio emitido pelo órgão de controle e não das contas propriamente ditas, isto é, não decidem acerca da execução global do orçamento, deliberam somente sobre o acatamento ou não da peça técnica emitida pelos tribunais de contas.

Os membros do Legislativo muitas vezes seguem o parecer dos Tribunais de Contas sem em nada acrescentarem com a sua participação ao controle. Não discutem a regularidade das contas, apenas votando em consonância ou não com o parecer do Tribunal de Contas do Estado.

Diante do exposto, explicita-se o que configura uma realidade nas Câmaras Municipais do Estado do Paraná: a falta de preparo e qualificação de seus membros para analisarem as contas municipais e a conseqüente falta de legitimidade e autoridade em seus pareceres. 


\section{Termo julgamento e oportunidade de defesa}

Existe divergência a respeito de se possibilitar ou não àquele que estiver tendo suas contas analisadas a oportunidade de exercer o contraditório e a ampla defesa perante o Legislativo.

Existe uma discussão doutrinária a respeito do termo "julgar" consagrado pela Constituição no seu art. 49, que trata da função atípica do Legislativo de fiscalizar e julgar as contas do Executivo. Reside a divergência da doutrina e dos Tribunais em se posicionar pelo caráter administrativo ou judicial desta função atípica.

Qualquer que seja o posicionamento adotado o Legislativo deverá oportunizar a defesa, uma vez que o art. 5ㅇ, LV da Constituição Federal assegura aos litigantes em processo judicial ou administrativo e aos acusados em geral o contraditório e ampla defesa.

Há de se ressaltar que o princípio do contraditório foi postulado como princípio da Administração Federal no artigo 2º, caput, da Lei. 9.784/99. Este princípio integra o devido processo legal administrativo, obrigando à Administração cientificar os administrados sobre a existência e o conteúdo dos processos que versem sobre seus interesses individuais.

Os argumentos dos defensores da tese de que o controle não se trata de julgamento e que, portanto, pode prescindir do contraditório e da ampla defesa, refere-se ao fato de que a apreciação por parte do Legislativo é política, não havendo a instauração de um processo, e que, o que se "julga" são as contas e não o Prefeito. Para os que assim entendem, não haveria litígio nem acusação, o que faz com que geralmente o julgamento pela Câmara de Vereadores ocorra sem que se proporcione ao Prefeito a oportunidade de defesa.

Em comentário ao art. 5ํ, LV, Amaral (2000, p. 40) defende que o legislador buscou, desse modo, atingir não somente os processos judiciais e administrativos, como também qualquer espécie de processo que tenha a possibilidade de ameaça ou de lesão a direito.

Considerando que a decisão sobre a regularidade ou não das contas tem implicações políticas, administrativas, civis e penais, e afeta direito ligado ao patrimônio e a liberdade das pessoas, será imprescindível o contraditório e a ampla defesa. 
Uma das conseqüências da desaprovação das contas, sob o fundamento de irregularidade insanável, é a inelegibilidade ${ }^{6}$ superveniente do administrador público por cinco anos contados a partir da decisão que as julgou. Ocorre que, proposta ação para desconstituir a decisão que rejeitou as contas anteriormente à impugnação, fica suspensa a inelegibilidade. Assim dispõe a Lei Complementar no 64/90 no seu art 1ㅇ, I, g:

Art. 1o São inelegíveis: I - para qualquer cargo: g) os que tiverem suas contas relativas ao exercício de cargos ou funções públicas rejeitadas por irregularidade insanável e por decisão irrecorrível do órgão competente, salvo se a questão houver sido ou estiver sendo submetida à apreciação do Poder Judiciário, para as eleições que se realizarem nos 5 (cinco) anos seguintes, contados a partir da data da decisão.

O Tribunal Superior Eleitoral sumulou neste sentido:

Proposta a ação para desconstituir a decisão que rejeitou as contas, anteriormente à impugnação, fica suspensa a inelegibilidade (LC 64/90, art. 1ำ I, g, Súmula 1-TSE).

Resta claro que da possibilidade de se propor uma ação não há como se afastar da litigiosidade e contenciosidade no julgamento das contas públicas, uma vez que pode resultar num processo punitivo que é a inelegibilidade.

Quando a irregularidade que se constata é sanável, sendo as contas parcialmente aprovadas, as conseqüências podem ser a inscrição em dívida ativa do nome do administrador e a execução. De qualquer maneira, o julgamento das contas implica em conseqüências mais ou menos gravosas e que, portanto, exige a participação do interessado em todas as fases do processo.

Uma vez que a deliberação da Câmara Municipal para aprovar ou desaprovar as contas prestadas anualmente pelo Prefeito constitui "julgamento", seja de caráter administrativo ou judicial, deve ser observado o preceito constitucional do contraditório e da ampla defesa. Sendo desrespeitados, tornará inválido o ato que culminar na rejeição das contas. Neste sentido posiciona-se Costa, N. (1999, p. 267):

6 Elegibilidade é a capacidade de o cidadão poder vir a exercer atos que impliquem ou culminem na sua eleição, pelo povo, mediante o exercício do voto direto e secreto, nos termos do caput do art. 14 da CF/88. É o direito de ser votado, capacidade eleitoral passiva. 
O caráter de julgamento administrativo implica que devem ser garantidos ao órgão que tenha suas contas apreciadas, bem como aos gestores da coisa pública, os direitos do devido processo legal, especialmente a ampla defesa e o contraditório, além dos preceitos da legalidade, impessoalidade, moralidade, publicidade, e eficiência. Não se há de admitir que o julgamento administrativo seja feito sem a notificação do Chefe do Poder Executivo que tenha suas contas apreciadas, por via postal ou por publicação na imprensa oficial, como ocorre em leis orgânicas dos Tribunais de Contas dos Estados ou dos Municípios, pois, do contrário, estar-se-ia cerceando na defesa, cuja amplitude está assegurada pelo inciso LV do art. 5o da Constituição Federal (destacou-se).

As garantias da ampla defesa e do contraditório asseguram o direito de ser ouvido, apresentando ao menos alegações orais, antes de sofrer a punição. Silveira (2001, p. 332) posiciona-se no seguinte sentido:

\begin{abstract}
Para ter eficácia, o procedimento deve se iniciar com uma notificação ao servidor de que está se apurando determinado fato, imputado a ele, na qual ele é convidado a apresentar sua defesa prévia e a acompanhar a oitiva de testemunhas e a produzir as provas que lhe interessem para sua defesa: indicação de suas próprias testemunhas, realização de perícias, juntada de documentos, etc., só depois disso é que a sanção pode ser aplicada, isso pela autoridade competente, nos termos da lei.
\end{abstract}

A Administração Pública tem a obrigação de comunicar ao administrado a existência de um ato administrativo que pode afetar sua esfera de direitos individuais. Muitas vezes, por se tratar de Municípios pequenos, o antigo chefe do Executivo toma conhecimento por terceiros de que teve a prestação de contas de sua gestão desaprovada.

Isso ocorre pelo fato de que os regimentos internos das Câmaras Municipais, muitas vezes anteriores à Constituição Federal de 1988, não consagraram a possibilidade da ampla defesa e do contraditório da autoridade que está tendo suas contas julgadas. Estes regimentos internos devem ser periodicamente revistos a fim de adaptarem-se às mudanças sociais, políticas e constitucionais.

Deve ser salientado que, podendo o Legislativo derrubar o parecer prévio do Tribunal de Contas quando este recomenda a desaprovação por falta de documentos ou irregularidades meramente formais, estas irregularidades podem ser supridas quando da defesa do agente junto ao Legislativo, fornecendo os elementos e esclarecimentos necessários ao julgamento. 
A possibilidade de defesa também serve para que aquele que esteja tendo suas contas julgadas verifique se o Legislativo adotou os procedimentos corretos no seu julgamento. Constitui uma maneira de fiscalizar sua atuação.

Apesar de os regimentos internos não disporem sobre o momento em que deva ser oportunizada a possibilidade do agente exercer sua defesa, interpreta-se que deva ocorrer antes da votação do projeto de Decreto Legislativo pelo Plenário.

\section{Votação do Decreto Legislativo}

Quando submetido a votação o projeto de Decreto Legislativo, a decisão da Câmara poderá acompanhar o parecer do Tribunal de Contas ou rejeitá-lo. Conforme explicita Bastos (1993, p. 286) "a manifestação da Corte de Contas não é definitiva; ela apenas instrui, subsidia, orienta as decisões dos vereadores, que poderão seguir o parecer ou rejeitá-lo". A decisão definitiva compete ao Legislativo que declara a regularidade ou não das contas.

A Constituição Federal outorgou ao Legislativo Municipal a possibilidade de fazer deixar de prevalecer o parecer prévio do Tribunal de Contas pelo voto da maioria qualificada dos membros da Câmara Municipal. Trata-se de uma exceção que ocorre na esfera municipal, não observada nos níveis estadual e federal. Dispõe a Constituição Federal ${ }^{7}$ no art. 31, § 20:

Art. $31[\ldots]$

§ 2ㅇ - O parecer prévio, emitido pelo órgão competente sobre as contas que o Prefeito deve anualmente prestar, só deixará de prevalecer por decisão de dois terços dos membros da Câmara Municipal. (destacou-se)

Sobre o tema observa Guerra (2003, p. 67):

Ademais, tal parecer é citado por alguns como anomalia à pretendida autonomia político-administrativa destinada aos Municípios brasileiros, tendo o constituinte originário de 1988 determinado um tratamento diferenciado a um dos entes federados sem haver fundamentação lógica.

7 A Constituição Estadual do Paraná, por sua vez, apenas repetiu os ditames da Constituição Federal, fazendo-o no texto do Art. 18, § 2ㅇ: “O parecer prévio, emitido pelo órgão competente, sobre as contas que o Prefeito deve anualmente prestar, só deixará de prevalecer por decisão de dois terços da Câmara Municipal". 
Sendo decisão do Legislativo rejeitar o parecer prévio do Tribunal de Contas, a votação prescindirá do quorum de maioria qualificada ${ }^{8}$ dos membros da Casa. Se a Câmara decidir de acordo com o opinado pelo Tribunal de Contas não haverá a necessidade de se observar o quorum mínimo.

\begin{abstract}
A força do Legislativo só é enfraquecida pela presunção de veracidade com que chega o parecer à Câmara. Sim, em princípio, o parecer vem dotado de força quase decisiva. Basta que não haja pronunciamento da Câmara ou que, em havendo tal externação de vontade, não atinja ela o elevado quorum de dois terços dos membros para que o teor do parecer se transforme em decisão definitiva. A manifestação técnico-contábil do Tribunal de Contas assume, portanto, um papel extremamente relevante (BASTOS, 1993, P. 286).
\end{abstract}

Há regimentos internos que dispõem que o projeto de Decreto Legislativo será aceito ou rejeitado pelo voto de 2/3 (dois terços) dos Membros da Câmara Municipal, no mínimo. Trata-se de dispositivo inconstitucional, uma vez que a Constituição Federal dispõe que somente nos casos em que "deixará de prevalecer" o parecer do Tribunal de Contas é que deverá ser respeitada a maioria qualificada.

Votando o Legislativo pela rejeição das contas, as mesmas serão imediatamente remetidas ao Ministério Público para os fins legais. Mesmo as contas tendo sido aprovadas, o agente público não terá imunidade civil ou criminal, pois, havendo lesão ao Erário, haverá a responsabilidade pelo dano que causou.

As decisões deverão ser publicadas no Órgão Oficial do Município em atendimento ao princípio da publicidade e transparência dos atos da Administração Pública, bem como faz-se necessário dar ampla divulgação do fato, não somente por meio da imprensa oficial, mas principalmente pelos meios mais acessíveis à população para que realmente esta tome conhecimento dos fatos, uma vez que a população, de uma maneira geral, não tem acesso fácil ao órgão oficial do Município.

8 O quorum de maioria qualificada é tomado sempre em relação ao número total de membros da Câmara Municipal, presentes e ausentes à votação. Segundo Meirelles (2001, p. 617) "para as deliberações em que se exigem quorum especial e aprovação por maioria absoluta ou qualificada toma-se sempre por base $o$ número total de vereadores que legalmente integram a Edilidade. As eleições e deliberações realizadas em desacordo com esse critério são ilegítimas e invalidáveis por via judicial". 


\section{Julgamento ficto}

Há regimentos que dispõem que, decorrido o prazo sem o julgamento pela Câmara Municipal, as contas serão aprovadas ou rejeitadas de acordo com o parecer prévio do Tribunal de Contas do Estado. É o que se chama de julgamento ficto.

Ocorre que as funções do Estado devem desempenhar suas atribuições com responsabilidade, e não com omissão, delegando suas competências a outros órgãos sem que Ihe seja imputada qualquer conseqüência. De acordo com Di Pietro (2002, p. 599):

O controle constitui poder-dever dos órgãos a que a lei atribui essa função, precisamente pela sua finalidade corretiva; ele não pode ser renunciado nem retardado, sob pena de responsabilidade de quem se omitiu (destacou-se).

Trata-se, na verdade, de poder-dever de fiscalização, já que, uma vez determinado em lei, não poderá ser renunciado ou postergado, sob pena de responsabilização por omissão do agente infrator (GUERRA, 2003, p. 23) (destacou-se).

Como é de competência exclusiva do Legislativo a decisão final sobre as contas, poder-se-ia concluir pela inconstitucionalidade desse dispositivo, por tratar-se de delegação de função típica do Legislativo ao Tribunal de Contas, o que é inconcebível pela Constituição Federal.

\section{Motivação do Decreto Legislativo}

O Legislativo tem a obrigatoriedade de motivar o Decreto Legislativo que julga as contas do Executivo, pois para Mello (2004, p. 102-103):

O fundamento constitucional da obrigação de motivar está - como se esclarece de seguida - implícito tanto no art. 1으. II, que indica a cidadania como um dos fundamentos da República, quanto no parágrafo único deste preceptivo, segundo o qual todo o poder emana do povo, como ainda no art. 5ㅇ, XXXV, que assegura o direito à apreciação judicial nos casos de ameaça ou lesão de direito. É que o princípio da motivação é reclamado quer como afirmação do direito político dos cidadãos ao esclarecimento do 'porquê' das ações de quem gere negócios que lhes dizem respeito por serem titulares últimos do poder, quer como direito individual a não se assujeitarem a decisões arbitrárias, pois só têm que se conformar às que forem ajustadas às leis.

Por isso Ramón Real disse que o dever de motivar é exigência de uma administração democrática - e outra não se concebe em um Estado que se declara 'Estado Democrático de Direito' (art. 1ำ, caput) -, pois o mínimo que os cidadãos podem pretender é saber as razões pelas quais são tomadas as decisões expedidas por quem tem de servi-los (MELLO, 2004, p. 103). 
Assim posiciona-se Castro (2003, p. 33):

\begin{abstract}
Destarte, é detentora a Câmara Municipal da função fundamental de julgar as contas (no exercício do controle externo, art. 31, caput, CR, e 180, da Constituição Mineira) do Executivo, em consonância com o disposto nos incisos IX e X do art. 93 da Constituição da República, a exigir do Judiciário que fundamente suas decisões, quer jurisdicionais, quer administrativas - regras estas que se aplicam aqui não só por simetria, sobretudo em razão da garantia de ampla defesa insculpida no art. 50, LV, CR -, não pode, em absoluto, o órgão julgador, aqui a Câmara Municipal, deixar de motivar seu julgamento no juízo político de controle externo de fiscalização do Município (grifos do autor).
\end{abstract}

O Decreto Legislativo deve indicar os motivos que levaram o Legislativo a tomar sua decisão, tendo em vista que poderá acarretar conseqüências gravosas. Dessa forma viabiliza o contraditório e a ampla defesa, contestando-se os dados constantes da peça, por meio de remédio jurídico cabível. Castro (2003, p. 37) ressalta:

De conseqüência, faltando os desdobramentos diretos do contraditório, a saber, de um lado, a informação prévia e geral dos atos sujeitos a julgamento, a ouvida do prestador - interessado direto - e a motivação, e, de outro lado, e em conseqüência, a oportunidade de reagir àquelas informações, com direito de presença e de audiência, desconhecendo-se as manifestações postas e não se tendo a motivação, que influi sobre a decisão final, ter-se-á a nulidade do mesmo julgamento, de pleno direito (destacou-se).

Há disposições regimentais no sentido de que sendo a deliberação da Câmara contrária ao parecer prévio do Tribunal de Contas, o projeto de decreto legislativo deverá conter os motivos da discordância. Tal dispositivo deve ser interpretado sistematicamente e extensivo à qualquer decisão da Câmara e assim atender ao princípio da publicidade, do contraditório e da ampla defesa.

Não apenas o Decreto Legislativo que rejeita o parecer prévio deve ser motivado, mas também o que concorda com os seus termos, pois como real titular do controle externo, ao Legislativo cabe a decisão final sobre as contas do Executivo. $O$ parecer do Tribunal de Contas tem função opinativa e não decisiva, não vinculando seus termos à decisão final. 


\section{Análise da eficiência do controle externo}

A questão do controle sobre a Administração Pública se relaciona intimamente à corrupção. Constata-se que quanto mais efetivos os mecanismos de controle, menores seriam os índices de corrupção no País. A realidade dos fatos mostra que este controle tem fugido à sua finalidade na busca por uma Administração Pública proba.

A história do País comprova que os representantes populares, em verdade, defendem os seus próprios interesses, sendo a corrupção e o desvio de verbas públicas práticas rotineiras na Administração Pública. Os dados veiculados na Revista Veja no 1851 de 28 de abril de 2004, p. 40-41, permitem concluir pela ineficácia do controle:

\footnotetext{
107 bilhões de reais - é quanto movimentam por ano as 5.560 prefeituras do país, entre recursos próprios, estaduais e federais;

20 bilhões de reais - é quanto se estima que suma todos os anos no ralo da corrupção aberto nas prefeituras brasileiras;

$400 \%$ - é quanto aumentou a média de desvio de recursos federais pelas prefeituras nos últimos cinco anos;

60.000 - é o número de vereadores no país. Pela lei, há um excesso de 9.000, mas os políticos resistem a reduzir;

1.500 - é o número de cidades no país que gastam mais com vereadores do que com necessidades da população;

600 - é o número de municípios criados artificialmente na última década, apenas para ter acesso a repasses de verba.
}

A credibilidade dos órgãos responsáveis pelo controle está afetada, explicitando a crise por que passa o modelo atual de controle externo. Em reportagem da mesma revista (Revista Veja, p. 43) constata-se a falta de legitimidade dos órgãos responsáveis pelo controle:

Em São Paulo, uma extensa pesquisa realizada pelo Instituto Transparência Brasil descobriu que, numa lista de dezoito órgãos públicos, os dois que a população considerou mais corruptos são a Câmara de Vereadores e o Tribunal de Contas do Município - dois órgãos que, em tese, deveriam ajudar a fiscalizar a prefeitura.

Conforme assevera Medauar (1998, p. 408-409):

A função de controle sobre o Executivo aparece hoje como inerente ao Legislativo, em qualquer regime de governo do mundo ocidental. Mas, independentemente das peculiaridades do regime de governo, que propiciaram maior ou menor intensidade do controle, registra-se descrença genérica quanto à eficácia e mesmo operacionalidade da fiscalização parlamentar. Paradoxal, assim, que se afirme, ao 
mesmo tempo, a relevância da função de controle do Legislativo e a escassez de resultados dessa atuação.

A respeito da maneira como o controle tem atuado, expõe Bastos (1996, p. 336):

De fato este se traduz numa das grandes prerrogativas do Poder Legislativo e, se fosse devidamente exercido, poderia servir de barreira para os desvios administrativos; no entanto, lamentavelmente o próprio Poder Legislativo se desmanda e se irmana com o Poder Executivo na prática de atos ilegais, mas aqui nós já estamos diante da patologia e não da normatividade.

Os motivos que levaram a essa ineficiência, analisa Medauar (1998, p. 409):

Vários fatores vêm apontados para justificar esse quadro: falta de interesse político na realização concreta e eficaz da vigilância, para não desagradar ao detentor do Poder Executivo; ausência, em geral, de sanção, pois nem o Congresso, nem suas comissões podem anular ou modificar atos administrativos ou aplicar sanções a administradores.

Dentre outras irregularidades efetuadas pela Câmara de Vereadores quando do exercício da sua função de fiscalizar e julgar as contas públicas, aponta Amaral (2000, p. 59):

Destarte, constata-se que, em determinadas ocasiões, por desconhecimento, as Câmaras Municipais procedem ao julgamento das contas do administrador público sem que sejam estudadas pela Comissão de Finanças, Orçamento e Tomada de Contas e, conseqüentemente, sem o necessário parecer para ser apreciado em plenário. Simplesmente vota-se o parecer técnico do Tribunal de Contas do Estado. Outras oportunidades, a Câmara Municipal encaminha o processo de prestação de contas à referida Comissão, esta emite o seu parecer e se procede ao julgamento pelo plenário da Câmara sem que seja dada ciência de qualquer ato ao administrador. Ainda, em outras, a Comissão oportuniza ao administrador a ciência dos atos, inclusive de defesa, e, contudo, se desprezam as alegações escritas, as provas e as alegações orais, julgadas sem qualquer atenção a esses elementos, simplesmente ignorando-os. Enfim, transgridem-se constantemente as normas e princípios constitucionais e infraconstitucionais. A gravidade disso é indiscutível. Inadmite-se comportamento dessa estirpe em um Estado Democrático de Direito (AMARAL, 2000, p. 59-60).

A grande deficiência desse controle se deve ao fato de que, de uma maneira geral, os vereadores não analisam o aspecto técnico do processo de prestação de contas, e isso ocorre por dois motivos: ou porque não têm interesse de fazê-lo porque já estão determinados a aprovar ou desaprovar, dependendo do acordo político que firmaram; ou porque não possuem condições intelectuais para tanto, mas que mesmo nessa situação não 
solicitam o apoio de peritos como tem direito pelo Regimento Interno de sua Casa Legislativa.

Apesar de oficialmente a finalidade da participação do Legislativo ser a de efetivar uma fiscalização sobre as contas, garantindo a probidade na Administração Pública, o que se observa é que se trata de uma maneira de oportunizar a impunidade para aqueles que conseguem apoio político para aprovar suas contas, mesmo estando irregulares. Uma maneira de restar legalizada a vontade política e não a técnica. A impunidade à probidade.

Observa-se a insuficiência normativa para tornar o controle mais rígido e assim impedir que acordos políticos interfiram na decisão sobre as contas do Executivo. Esta causa estimula a corrupção e a impunidade, porque se aprovam contas que deveriam ser reprovadas, tão só por acordo político e troca de favores.

Conclui-se que o controle não funciona porque foi feito para não funcionar. Foi criado por aqueles que se alimentam do sistema. A conseqüência é a impunidade, pois se possibilita que por acordo político se tenha a aprovação de prestação de contas tecnicamente classificada como irregular.

O resultado da atuação deste controle é lamentável. As consequências devastadoras, uma vez que as verbas estão sendo livremente desviadas quando poderiam ter sido investidas no desenvolvimento do País, amenizando o quadro que se tem de um País de miséria, violência, desigualdade social e descrença no próprio Estado. A crise institucional e a descrença nos representantes populares têm como conseqüência a crise de legitimidade.

Pode-se concluir que o controle externo tem se mostrado ineficiente. Esta deficiência deve ser discutida a fim de que as mudanças possam ocorrer.

Para que o controle possa alcançar sua finalidade, é preciso que se dê nova interpretação aos dispositivos constitucionais que tratam do assunto, não se permitindo mais que aspectos políticos se imiscuam na aprovação das contas. É preciso que se encare o assunto com seriedade e principalmente com respeito à população, titular do patrimônio público que está sendo livremente desviado em decorrência de uma interpretação Constitucional que possibilita arranjos políticos no controle das contas públicas.

\section{Conclusão}

Diante do exposto, pode-se registrar as seguintes conclusões: 
Por não serem, muitas vezes, os membros das Comissões de Finanças e Orçamento dotados de especialidade técnica para exercerem sua função, é possível que se questione a legitimidade de seus pareceres.

A Câmara Municipal deve oportunizar àquele que estiver com suas contas sob análise e julgamento o exercício do contraditório e da ampla defesa, uma vez que esse direito é assegurado pela Constituição Federal.

A decisão de aprovação proferida pelos membros da Câmara Municipal está contida em Decreto Legislativo e deve ser motivada tendo em vista que é exigência de uma Administração democrática. Deve o povo, real titular do Poder, ser informado das decisões tomadas pelo Estado.

A exigência de motivação do Decreto Legislativo, sob pena de invalidade, também se deve ao fato de que, uma vez que a decisão pode se tornar danosa deve indicar as parcelas impugnadas para que se possa estabelecer o contraditório e a ampla defesa em nível administrativo e judicial.

O julgamento ficto pode ser considerado inconstitucional, uma vez que é de competência exclusiva do Legislativo a decisão final sobre as contas. Não pode delegar a sua função típica a outro órgão sem que a Constituição tenha previamente previsto esta possibilidade.

Observa-se a falta de conhecimento, despreparo ou mesmo má-fé dos vereadores que não atuam em conformidade com o ordenamento jurídico vigente, muitas vezes não analisando o processo de prestação de contas, votando apenas pela aceitação ou não do parecer prévio do Tribunal de Contas.

Sendo a finalidade do controle zelar pelo Erário e pela probidade na Administração Pública, conclui-se que o controle externo não deveria possibilitar o julgamento das contas baseado em acordos políticos, desmerecendo-se os aspectos técnicos, pois desta maneira possibilita-se a corrupção e a impunidade.

\section{Referências}

AMARAL, Getúlio Sérgio do. Direito à defesa do prefeito nos julgamentos das contas municipais: aplicabilidade do devido processo legal e da ampla defesa aos julgamentos das contas do administrador municipal pela câmara municipal: doutrina, jurisprudência e legislação. Belo Horizonte: Inédita, 2000. 
BASTOS, Celso Ribeiro. Curso de direito administrativo. 2. ed. São Paulo: Saraiva, 1996.

BASTOS, Celso Ribeiro; MARTINS, Ives Gandra da Silva. Comentários à Constituição da Brasil: promulgada em 5 de outubro de 1988. São Paulo: Saraiva, 1988-1993.

CASTRO, José Nilo de. Julgamento das contas municipais. 3. ed. Belo Horizonte: Del Rey 2003.

COSTA, Nelson Nery. Curso de direito municipal brasileiro. Rio de Janeiro: Forense, 2000.

DI PIETRO, Maria Sylvia Zanella. Direito administrativo. 14. ed. São Paulo: Atlas, 2002.

GUERRA, Evandro Martins. O controle externo e interno da administração pública e os tribunais de contas. Belo Horizonte: Fórum, 2003.

MEDAUAR, Odete. Direito administrativo moderno. 2. ed. São Paulo: Revista dos Tribunais, 1998.

MEIRELLES, Hely Lopes. Direito administrativo brasileiro. 24. ed. São Paulo: Editora Malheiros, 1999.

Direito municipal brasileiro. 12. ed. São Paulo: Editora Malheiros, 2001.

MELLO, Celso Antônio Bandeira de. Curso de Direito Administrativo. 17. ed. São Paulo: Malheiros Editores, 2004.

REVISTA VEJA. O perdulário municipalismo brasileiro. Seção Brasil. no 1851, de 28 de abril de 2004.

SILVEIRA, Paulo Fernando. Devido processo legal. 3. ed. Belo Horizonte: Del Rey, 2001.

SOUZA, Hilda Regina Silveira Albandes de. Controle externo da administração pública estadual e municipal. Possibilidades e limites da fiscalização das casas parlamentares e do Tribunal de Contas. In: Revista Trimestral de Direito Público 13/1996. São Paulo: Malheiros Editores, 1996. 